\title{
The Development of Otomotive Electrical and Electronic Practice Teaching Material on Otomotive Field of SKKNI Based to Improve Student Majoring Achievement Standard Competence in Polytechnic
}

\author{
I Komang Rusmariadi ${ }^{1}$, I Putu Darmawa ${ }^{2}$, I Putu Sastra Negara ${ }^{3}$ \\ Mechanical Engineering \\ Bali State Polytechnic \\ Bali, Indonesia \\ ${ }^{1}$ rusmariadi@yahoo.com, ${ }^{3}$ putusastranegara@pnb.ac.id
}

\begin{abstract}
This progress report contains about the achievement of the implementation of the program of research in the development of teaching materials in the form of an integrated jobsheet. The second stage of the development will be done in $\mathbf{2 0 1 8}$ with the goal to find: 1 ) the evaluation result from the expert, lectures, and students, 2) the obstacles during the try out, and 3) the feasibility of the jobsheet draft as a lab teaching material.

Research using Dick \& Carey development model, in review and test the research involving 2 experts, 7 course lecturerss, and 24 students in mechanical engineering department. Data obtained using questionnaire enclosed and open questionnaire. Data were collected in the form of comments and suggestions as well as the evaluation result toward the integrated jobsheet were analyzed by descriptive qualitative and quantitative improvement. The test results stated: 1) thet content expert test is very decent; design / media expert is very decent; individual very decent; small group is very decent; and field testing of students and lecturer decent and very decent. 2) components that need to be revised from the entire contents of the test results and instructional design experts to field test were: the contents of the summary should be more material-oriented than the summary of jobsheet parts, in addition to trouble shooting ignition problems, it is necessary to add maintenance material that is preventive maintenance, assessment rubrics for evaluation / practical tasks need to be made in more detail from simple to complex practices. Summary and evaluation analysis tools must be clear, the amount of test practice material so that there is a balance of theory and practice, the size of the book should be chosen for an elegant appearance, especially if proposed to ISBN.

Based on test data and analysis of the abovementioned, teaching material draft can be declared eligible as the practical of teaching jobsheet. This research only reached the stage of formative evaluation on Jobsheet, it is expected in the future to do more research to determine its effectiveness in an effort to increase the competence of students.
\end{abstract}

Keywords--- development; jobsheet integrated; competency standards; Polytechnic

\section{INTRODUCTION}

Polytechnic is a professional institute higher education oriented to the needs of industry and ready-made resilience of learners become members of the community who have professional skills in their respective fields. In order for students or graduates of Polytechnics to be more competitive in the industrial world can be used in the world of work, of course they must have the competencies needed by the industry. Jobsheet in electricity and automotive electronics practices based on SKKNI must be able to cover all competencies needed by the industry as formulated in the curriculum [7].

Jobsheet as a practical teaching material used in the practice of electricity and automotive electronics majoring in mechanical engineering at Bali State Polytechnic has not fulfilled the demands of the applied curriculum, the number is very limited, meaning that it has not fulfilled the number of job practices available in electrical and automotive electronics practices. Judging from the scope of the material content, the number of jobsheets is still lacking which supports the Indonesian National Work Competency Standards (SKKNI) in the automotive sector, nor has the formulation of basic competencies and competency standards been found by students [6]. In addition, the evaluation aspects listed in the jobsheet show learning evaluations that do not focus on measuring the competencies achieved by students every time they finish learning per competency. Likewise, the implementation of evaluations in the form of tests developed by lecturers, emphasizes more on understanding cognitive content, has not focused on measuring attitudes and skills of students in the form of action tests (performance test). This condition has the potential to produce graduates who are not in accordance with the expected competency standards. [1]

As a practical teaching material, an integrated Jobsheet is a practical learning tool where the learning sheets are organized into a single unit. The learning sheets include: information sheets, instruction sheets, operation sheets, 
self check sheets, and evaluation sheet tools. Measurement of competency achievement in the action test sheet (porphomance test). These learning sheets are not separated from each other or must be an integral whole to achieve learning goals (Dick \& Carey, 2007). Referring to the problems above, it is necessary to improve the effectiveness and efficiency of the implementation of the electrical and automotive electronics program which is carried out by increasing the relevance and systematization of the jobsheet structure in accordance with competency requirements [4].

Thus an integrated jobsheet is needed for electrical and automotive electronics practices that are business oriented to support the improvement of student competency achievement. The results of the first year research (2017), have obtained drafts of electrical practice and automotive electronics textbooks based on the Indonesian National Work Competency Standards (SKKNI). Jobsheet's draft or prototype, the material is developed based on competency standards, basic competencies, and indicators of achieving competence. The main material of electrical and automotive electronics practice consists of 5 parts, namely: 1) conventional ignition system 2) electronic ignition system 3) body electrical system 4) filling system and 5) starter system. This development research is carried out in two phases, the first phase is carried out in 2017 , and has received a jobsheet draft. The second phase is carried out in 2018 with the aim of knowing: 1) the results of the assessment of experts, lecturers and students, 2) constraints that need to be revised during the trial, and 3) the feasibility of the jobsheet draft as practical teaching materials. [3]

Based on the preliminary survey of the research team, it concludes that there are two main issues in practical learning: 1) the absence of innovative practice learning modules, practical lecture materials as outlined in the lesson plan and Jobsheet less relevant to the Indonesian National Work Competency Standards (SKKNI) automotive field and 2) practice teaching method with lecture (conventional) still become habit of teaching team. Based on the background explanation above, the main problem of this development research is how is the draft form of teaching materials in the form of an integrated jobsheet based on SKKNI in automotive field for electrical engineering and automotive electronics courses that can improve the achievement of competence in students majoring in mechanical engineering of Polytechnic [6].

\section{METHOD}

\section{A. Types and Research Design}

This research material development study using the model of Dick \& Carey (2007) and designed to take place in two years. A summary of key activities, subjects and products to be achieved within two years can be briefly described in the following Table 1.

TABLE I. EXPECTED SUMMARY OF ACTIVITY AND PRODUCT IN THE SECOND STEP OF 2018

\begin{tabular}{|c|l|l|l|}
\hline Step & \multicolumn{1}{|c|}{ Main Activities } & \multicolumn{1}{|c|}{ Subject } & Product \\
\hline II-2018 & Jobheet testing & 1. Field & Practical \\
& 1. Conduct expert & experts & teaching \\
& test & Studies & materials In \\
\hline
\end{tabular}

\begin{tabular}{|l|l|l|l|}
\hline Step & \multicolumn{1}{|c|}{ Main Activities } & \multicolumn{1}{|c|}{ Subject } & \multicolumn{1}{c|}{ Product } \\
\hline & 2. Analyzes and & . Technolo & the form of an \\
& revisions I & gist & integrated \\
& 3. Conduct & Learning & jobsheet that \\
& individual testing & h. Assess & Vas been \\
& 4. Analysis and & ment & \\
& revisions II & Expert & \\
& 5. Conduct group & 4. College & \\
& test small & student & \\
& 6. Analysis and & f. Lecturer/ & \\
& revision III & Instructor & \\
& 7. Conduct a class & & \\
& test & & \\
8. Analysis and & & \\
revision IV & & \\
9.Dissemination & & \\
\hline
\end{tabular}

\section{B. Population and Sample}

The population of the study were students and lecturers of mechanical engineering, where the students were 140 people and 63 lecturers at the State Polytechnic of Bali. Samples were taken as many as 71 students distributed in three classes, namely engineering courses of classes IVA, IVB and IVC classes in 2018, and 7 lecturers special lecturer at Lab.Otomotif. In detail the state of the population is presented in the following Table 2.

TABLE II. SAMPLE POPULATION OF RESEARCH PREPARING THE PRACTICE OF PRACTICE MATERIALS IN THE ForM OF INTEGRATED JOBHEET AT BALI STATE POLYTECHNIC

\begin{tabular}{|l|l|c|c|}
\hline No & \multicolumn{1}{|c|}{ Study Program } & $\begin{array}{c}\text { Number of } \\
\text { Classes }\end{array}$ & $\begin{array}{c}\text { Number of } \\
\text { people }\end{array}$ \\
\hline 1. & $\begin{array}{l}\text { Student majoring mechanical } \\
\text { engineering (Smt IV) }\end{array}$ & 3 & 71 \\
$2 . \quad \begin{array}{l}\text { Lecturer/Instructor of } \\
\text { Mechanical Engineering at } \\
\text { Lab.Otomotif }\end{array}$ & - & 7 \\
\hline \multicolumn{1}{|c|}{ Amount } & 3 & 78 \\
\hline
\end{tabular}

\section{Second Year Development Procedure}

The activities carried out in the development of practical teaching materials in the form of this jobsheet are as follows: a)Determination of Trial design, b)determination of Try Out Subjects, c)Identifying Data, d)Establish Research Instruments.

\section{Data Analysis}

Data collected from questionnaires from expert responses, students, and lecturers were analyzed descriptively. The feasibility and criteria for product revision are as .[2]

TABLE III. FEASIBILITy LEVEL AND PRODUCT REVISION CRITERIA

\begin{tabular}{|c|c|}
\hline Scorecoards $(\%)$ & Eligibility \\
\hline $82,3-95,0$ & Very worth it \\
$69,7-82,3$ & Well worth it \\
$44,3-69,7$ & Quite decent \\
$31,7-44,3$ & Less feasible, needs to be revised \\
$19,0-31,7$ & Very unfeasible, it needs to be revised \\
\hline
\end{tabular}

\section{RESULTS AND DISCUSSION}

Research on the development of teaching materials in the form of an integrated jobsheet of Electrical Practices and Automotive Electronics based on the Indonesian National Work Competency Standards (SKKNI) in the automotive light vehicle sector at the stage of the 2nd year focused on developing the realm of review and trial, 
where the discussion focused on presenting and analyzing good data qualitative data in the form of responses and suggestions (revision) and quantitative which are the results of the assessment of teaching materials in the form of jobsheets developed.[8].

The development of electricity practice and automotive electronics teaching materials based on the automotive field SKKNI in the second year (2018) stage is conducted the feasibility test of teaching materials for students and lecturers and feasibility tests through content and design / learning media expert tests, as well as limited individual and field trials. The activities that have been carried out with the following results.

\section{A. Test Expert Learning Content}

The learning content expert is an expert in mechanical engineering and also at the same time a senior lecturer at Udayana University. As an assessor of the teaching materials for electrical and automotive electronics practices carried out by Ainul Ghurri Ph.D from the Faculty of Engineering, Udayana University, Denpasar. Competence Ainul Ghurri is an expert in mechanical engineering. Based on the data recapitulation the results of the assessment of the content of experts on the draft teaching materials for electricity and automotive electronics based on SKKNI in the automotive field of light vehicles is $95 \%$. In the open questionnaire, there are several inputs from the learning content experts that will be described in the discussion section.

\section{B. Test Design / Learning Media Expert}

Design experts / learning media were also asked to provide an expert in the field of learning technology from Undiksha. As a design and media expert, DR. I Made Pageh, M.Hum. His competence is one of the experts in the field of learning technology at the University of Education Ganesha Singaraja. Based on the data recapitulation of the assessment results of the learning design experts on the draft teaching materials for electrical and automotive electronics teaching practices based on the automotive field SKKNI obtained: 95.93\%. Through an open questionnaire, there are several inputs from design experts and learning technology that will be described in the discussion section.

\section{Field test for lecturer}

In this case, the field trial was also given to lecturers on electrical practice and automotive electronics courses through a questionnaire to assess the practical teaching materials being developed. The results of the lecturers' assessment through a closed questionnaire showed a percentage of $86.75 \%$. When converted into a range of feasibility and revision criteria for practical teaching materials with a level of achievement of a scale of 100 , this percentage is in a very decent qualification, so that revisions are made to the teaching material only according to suggestions from the lecturer as explained in the discussion section

Based on the results of the assessment of content and design experts as well as the assessment of electrical practice lecturers and automotive electronics can be described in the following diagram.

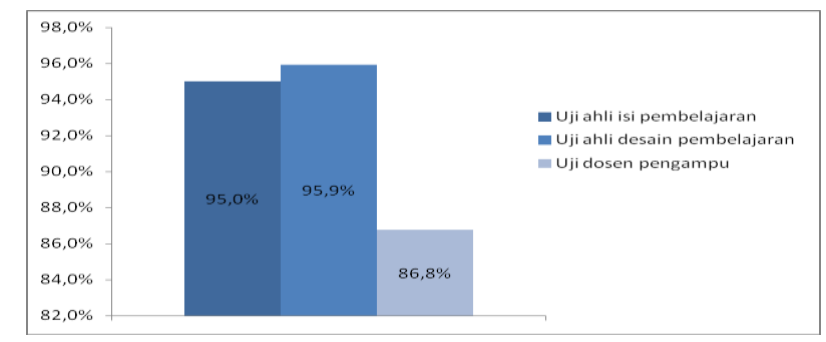

Fig. 1. Test Results for Content Experts,Learning Designs and Lecturers

\section{Individual and Small Group Test Results}

In this case the trial subject was a sixth semester student majoring in mechanical engineering at Bali State Polytechnic. Individual trial subjects are chosen randomly, as well. Small group trial subjects selected 6 students randomly based on the cluster of low, medium, and high ability of each cluster of 2 people.

Based on the calculation of the data recapitulation of the results of individual and small group trials of draft teaching materials on electricity practices and automotive electronics based on SKKNI in the field of automotive light vehicles obtained results: $84.38 \%$ and $84.82 \%$. Through an open questionnaire, there are a number of inputs from students which will be described in the discussion section.

\section{E. Field Trial Results}

The subjects of the field trial were VI semester students and lecturers of electrical and automotive electronics practice in the mechanical engineering department of Bali State Polytechnic. Field trials were conducted at the Bali State Polytechnic mechanical engineering department. The field test involved 7 lecturers and 24 students of the sixth semester. The average percentage of lecturer and student assessment results on practical teaching materials in the form of integrated jobsheet through an open questionnaire is $86.75 \%$ for the average score of the assessment of the lecturer group with some input that will be described in the discussion section. Based on the results of individual testing, small groups and field tests from students on the design of teaching materials in electronic and automotive electrical practices can be explained in the form of the following diagram.

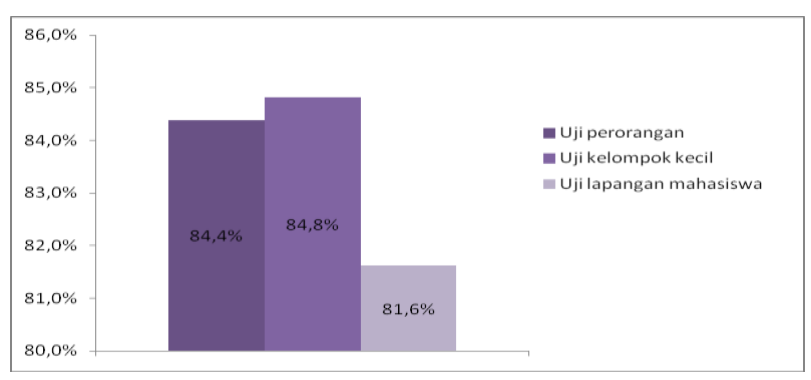

Fig. 2. Individual Test Results,Small Groups and Student Field Tests.

Research on the development of teaching materials in the form of an integrated jobsheet of electrical and automotive electronics practices based on the Indonesian National Work Competency Standards (SKKNI) in the light vehicle automotive sector at the stage of the 2 nd year 
focuses on developing the realm of review and trial, where the discussion is focused on the presentation and analysis of good data qualitative data in the form of responses and suggestions (revision) and quantitative which are the results of the assessment of teaching materials in the form of jobsheets developed.

Activities at the review or trial stage, the results of the development are carried out by evaluating the contents and design of learning media through expert content and design assessments. The product implementation in the form of jobsheet is carried out through individual, small group and field trials. The aim is to find out the effect on the quality of learning which ultimately aims to improve the achievement of the competency standards of students. Which includes changes, indicators of learning, content or content of learning materials, summaries, tests, answer keys, and others. Introduction includes completeness and clarity of content, sentence composition, ease, writing, attractiveness, and basic competencies (KD). The learning indicator (IP) includes the conformity of KD with IP, systemic compilation, formulation, presentation, and writing. The learning content includes the suitability of the material with IP, sequence, material description, presentation, and writing. The summary includes relevance to IP, source of test material, distribution of domains, number of items and writing. The answer key includes the correctness of the answer, meaning, writing and display. While others include effectiveness, attractiveness and efficiency of learning [5].

The implementation of this research is carried out only to formative evaluation, which deals with improvements to product development. The implementation carried out in this study is not comprehensive because in general there are only five jobs from the electrical and automotive electronics practice subjects. The last stage is to conduct evaluations which include formative evaluation and summative evaluation. Formative evaluation is carried out to collect results data at each stage that is used as reference in refinement while summative evaluation is carried out at the end of the program to determine its effect on student learning outcomes and the quality of learning broadly. At this stage of the research only formative evaluation was carried out, because this type of evaluation was related to the stages of development research to improve the development of the resulting teaching materials.

Based on the results of expert content and learning design assessment with a closed questionnaire on the subject of the development of teaching materials in the form of jobsheet Electrical Practices and Automotive Electronics, the assessment percentages were $95 \%$ and 95.93\% respectively. The amount of each percentage if converted into Table 3 . Regarding the level of eligibility and revision criteria with the conversion of the achievement level of the second 100 scale the percentage of the percentage is in a very decent qualification. This means that the practical teaching materials in the form of jobsheet are very suitable for the contents of the development material to be used as learning media in Electrical and Automotive Electronics Practices with the aim of increasing the achievement of polytechnic student competency standards and teaching materials only need to be revised sufficiently.
The revisions made to teaching materials based on input from content experts and learning design experts in Electrical and Automotive Electronics Practices are: 1) the details of the contents of the Information Sheet and Operation Sheet need to be detailed in the contents of the table of contents, 4) work safety has not been included in the competency basic and final learning objectives, 5) in addition to trouble shooting ignition problems, it is necessary to add maintenance / maintenance materials that are preventive maintenance, 6) assessment rubrics for evaluation / practical tasks need to be made in more detail (from simple to complex practices; or for example referring to psychomotor level in learning / psychomotor domain of learning), 7) summary and evaluation analysis tool must be clear, 8) the amount of practice test material so that there is a balance of theory and practice, it is recommended to make as many as 20 tests, 9) summary of teaching material transferred after the material of this guidebook, 10)the size of the book should be chosen so that the appearance is elegant, especially if it is proposed to the ISBN.

In the case of individual and small group trial subjects selected 1 and 6 students of the sixth semester majoring in mechanical engineering at Bali State Polytechnic were randomly selected based on the cluster of low, medium, and high ability of each cluster of 2 people. The percentage of their assessment through an open questionnaire on the development of practical teaching materials in the form of jobsheet was $84.38 \%$ and $84.82 \%$. When converted into Table 3 . About the level of eligibility and revision criteria with the conversion of the level of achievement of scale 100 then the category is very feasible and needs to be revised accordingly according to the input given by the student. Revisions made based on input during individual and small group trials of students on an open questionnaire include:1) the cover should be added to the D3 Mechanical Engineering study program, 2) use brighter colors in the guidebook writing 3) the instructional material was made in more detail, 4) the jobsheet preparation was made as interesting as possible so that it could attract student motivation.

In terms of the subject of field trials of the sixth semester students of mechanical engineering in number of 24 people. Showed that the percentage of the achievement of the development of practical teaching materials according to the student's assessment was $81.62 \%$. If the percentage is converted into Table 3 . About the feasibility and revision criteria for practical teaching materials at the level of achievement of 100, this means that the percentage of teaching materials in practice is in a proper qualification, so that teaching materials only require revisions according to suggestions and input from students, namely 1) overall need to add a lot of pictures of the ignition system and explanation, 2) between sample questions and answer keys are multiplied and need to be set more spacing distance, 3 ) how to assemble the ignition system components need to be explained in more detail, 4) jobsheet material made more detail, 5) need to add some picture information and clarify, 6) overall teaching materials on electrical practices and automotive electronics in the form of integrated jobsheets are good.

In this case, the field trial was also given to the lecturers of the Automotive Electrical and Electronics 
Practices subject through a questionnaire to assess the practical teaching materials being developed. The results of the lecturers' assessment through a closed questionnaire showed a percentage of $86.75 \%$. When converted into Table 3. Regarding the feasibility and criteria for revising practical teaching materials with a level of achievement of 100 , this percentage is in very decent qualifications, so that revisions are made to teaching materials only according to the suggestions of the lecturers, namely: 1) pictures enlarged so that the picture description is clear, 2) technical English terms on the self check sheet and operation sheet are written in italics, 3) real pictures need to be added to the operation sheet component, 4) in summary in addition to the practice procedure it is necessary to add practical material. ) instructional material needs to be developed sustainably along with the development of technology in the field, 6) overall the draft materials for teaching electrical and electronic practices are good.

\section{IV.CONCLUSION}

Based on the level of feasibility and revision criteria for the development of practical teaching materials that, quantitative data from the test results (assessments) of experts in the contents of teaching materials on electrical practices and automotive electronics with an average percentage: $95 \%$ stated very feasible, design experts and learning media: 95, 93\% said it was very feasible, individuals: $84.38 \%$ very decent, small groups: $84.82 \%$ very feasible. Whereas the field test from the lecturer at the level of feasibility: $86.75 \%$ said it was very feasible, from students: $81.62 \%$ said it was very feasible.

All assessment results on the development of teaching materials on electrical and automotive electronics practices, both from content and learning design experts to the results of field tests provide some input in the form of suggestions namely; 1) The contents of the summary should be more material-oriented than the summary of jobsheet parts, 2) in addition to trouble shooting ignition problems, it is necessary to add maintenance / maintenance materials that are preventive maintenance. 3) assessment rubrics for evaluation / practical assignments need to be made more detailed from simple to complex practices, 4) summary and evaluation analysis tools must be clear, 5) the number of practice test materials so that there are theoretical and practical balances, then 20 tests are recommended , 6) the size of the book should be chosen for an elegant appearance, especially if it is proposed to the ISBN.

Drafts of practical teaching materials in the form of integrated jobsheets material testing practices and metrology can be declared feasible as practical teaching materials.

\section{ACKNOWLEDGMENT}

The research team would like to express their special thanks to the head of the Mechanical Engineering Department for support during this research.

\section{REFERENCES}

[1] A. Sudrajat, How to Improve Motivation, Interest in Student Learning, http://akhmadsudrajat. wordpress.com/2010/09/11, 2010.

[2] Depdiknas and BSNP, Socialization of Standard Instruments for Textbook Appraisal Lesson on Technology, Information and Communication Lessons. Jakarta: BSNP and Bookkeeping Center, 2008.

[3] Depdiknas, Self Evaluation Documents Majoring in Mechanical Engineering. Denpasar: Politeknik Negeri Bali, 2006.

[4] W. Dick and L.Carey, The Systematic Design of Instruction, 3rd Edition, USA: Harper Longman, 2004.

[5] L. Noviana, Attitude, motivation, interest in learning math, http://www. slideshare.net/Interest_Matematika_2011, accessed March 27, 2012.

[6] E. W. Luhur, KEPMEN Skkni Automotive Light Vehicle, http://www.scribd.com/doc/39310005/Kepmen-SkkniAutomotive, accessedMarch25, 2017.

[7] Trianto, Constructivism-Driven Innovative Learning Models: Concepts, Theoretical-Practical Basis and Its Implementation. Jakarta: Achievement Library, 2007.

[8] M. Wena, Contemporary Innovative Learning Strategies. Jakarta: PT. Earth Script, 2009. 